\title{
Synthesis and Evaluation of a Cyclopropane Derivative of DHMEQ
}

\author{
Eiko Yasui,* Kan Takayama, Takahiro Nakago, Nobuyuki Takeda, Yasutada Imamura, and
} Shinji Nagumo*

Department of Applied Chemistry, Kogakuin University; 2665-1 Nakano, Hachioji, Tokyo 192-0015, Japan.

Received November 24, 2013; accepted December 19, 2013; advance publication released online December 26, 2013

Dehydroxymethylepoxyquinomycin (DHMEQ, 1) is well known to inhibit nuclear factor-kappa B (NF$\kappa \mathrm{B})$, which is closely associated with immune, inflammatory, and apoptotic processes as an inducible transcription factor. The inhibitory effect seems to be the result of the ring opening of an epoxide of 1 with $^{C_{y s}}{ }^{38}$ of $\mathbf{p 6 5}$. We have synthesized an analog 4 containing a cyclopropanated quinol skeleton and examined its ability to inhibit NF- $\kappa$ B. Surprisingly, 4 showed no remarkable NF- $\kappa$ B inhibitory activity as determined through expression of cyclooxygenase-2 (COX-2) in an RAW264.7 macrophage cell line.

Key words dehydroxymethylepoxyquinomycin (DHMEQ); cyclopropane; nuclear factor-kappa B (NF- $\kappa$ B); cyclooxygenase-2 (COX-2); RAW264.7

The recent growth in molecular biology has generated new drug targets causing a dramatic paradigm shift in the chemotherapeutics of cancer (e.g., molecularly targeted therapeutics). Recently, much attention has been concentrated on nuclear factor-kappa B (NF- $\kappa$ B), which belongs to a family of transcription factors associated with immune and inflammatory processes. NF- $\kappa \mathrm{B}$ is a homo- or heterodimer of Rel family proteins including p65 (RelA), p50, RelB, c-Rel, and p52. Among them, p65 (RelA), c-Rel, and p52 have a transactivation domain. Continuous activation of $\mathrm{NF}-\kappa \mathrm{B}$ is known to occur in various types of human tumors, and is correlated with inactivation of apoptosis via transcriptional misregulation. NF- $\kappa \mathrm{B}$ inhibitors are thus expected to be prominent candidates for anticancer drugs. ${ }^{1)}$ Dehydroxymethylepoxyquinomycin (DHMEQ, 1), first synthesized by Umezawa and colleagues on the basis of a structural modification of epoxyquinomycin $\mathrm{C}$ (Chart 1 ), shows a potent NF- $\kappa \mathrm{B}$ inhibitory effect with little toxicity. ${ }^{2}$ ) The careful matrix assisted laser desorption ionization-time of flight (MALDI-TOF)-MS analysis by Umezawa and colleagues of chymotrypsin-treated p65 peptide clarified that the bioactivity of $\mathbf{1}$ is a result of coupling with $\mathrm{Cys}^{38}$ of p65. ${ }^{3)}$ To specify the covalent bond formed, they conducted a reaction of 1 with $N$-Boc-L-Cys methyl ester. The resulting conjugate was identified as $\mathbf{2}$ based on its mass and
NMR spectra. Although the regioselective ring opening of the epoxide is essential for the additional inhibitory effect of $\mathbf{1}$ against p65, it has not yet been completely confirmed whether a similar chemical binding occurs in biological processes. In this paper, we describe the synthesis of a new DHMEQ analog $\mathbf{4}$ with a cyclopropane ring instead of an epoxide and the evaluation of its NF- $\kappa$ B inhibitory activity to clarify the significance of the epoxide in $\mathbf{1}$ using a structure-activity relationship study.

\section{Results and Discussion}

Because 3b also inhibits NF- $\kappa$ B activation, ${ }^{4)}$ synthesis of its analog 8 was initially conducted as shown in Chart 2. Dienone 5 was prepared from 2,5-dimethoxyaniline following a known procedure. ${ }^{5}$ Treatment of dienone $\mathbf{5}$ with trimethylsulfoxonium iodide in the presence of $\mathrm{NaH}$ resulted in selective cyclopropanation at the $\mathrm{C}_{4,5}$ double bond to generate 6 in $77 \%$ yield. ${ }^{6,7)}$ Deacetalization of $\mathbf{6}$ with pyridinium $p$ toluenesulfonate (PPTS) afforded the diketone 7 in excellent yield. Finally, reduction of 7 with L-selectride $^{\circledR}$ proceeded stereoselectively to give $\mathbf{8}$ with cis-configuration. Next, we attempted the conversion of $\mathbf{8}$ into the second target $\mathbf{4}$. After protection of the alcohol $\mathbf{8}$ with an acetyl group, the resulting acetate 9 was subjected to removal of an alloc group<smiles>O=C(NC1=CC(=O)C2OC2[C@H]1O)c1ccccc1O</smiles><smiles>O=C(NC1=CC(=O)[C@]2(CO)O[C@H]2[C@H]1O)c1ccccc1O</smiles>
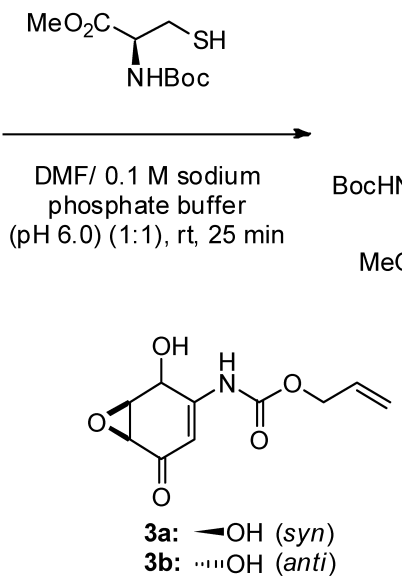<smiles>COC(=O)[C@H](CS[C@H]1C(=O)C=C(NC(=O)c2ccccc2O)[C@@H](O)[C@@H]1O)NC(=O)O</smiles><smiles>O=C(NC1=CC(=O)C2CC2[C@H]1O)c1ccccc1O</smiles>

Chart 1. Cyclopropane Derivative of DHMEQ

The authors declare no conflict of interest. 


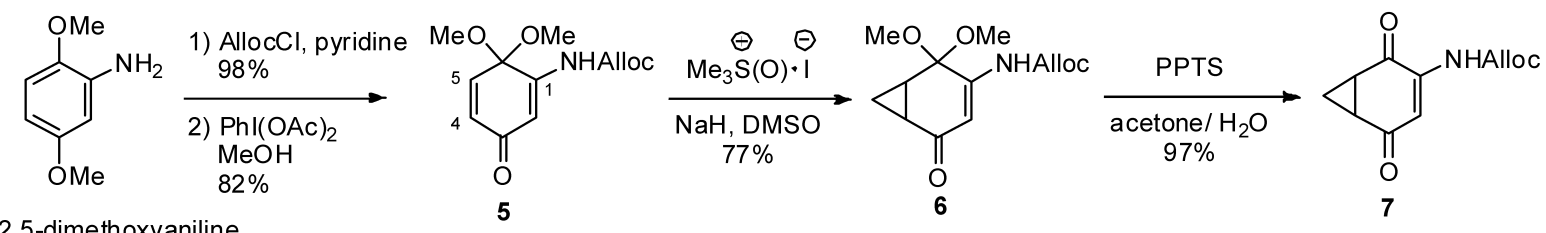

2,5-dimethoxyaniline

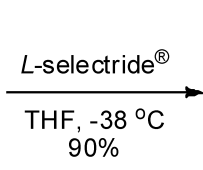

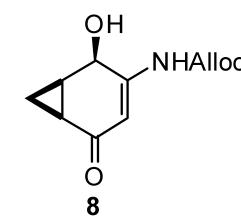<smiles>CC(=O)O[C@H]1C(NC2CCCCC2)=CC(=O)[C@@H]2C[C@@H]21</smiles><smiles>CC(=O)O[C@H]1C(N)=CC(=O)[C@@H]2C[C@@H]21</smiles><smiles>CNC1=CC(=O)C2CC2C1O</smiles>

$(10 / 11=5 / 2)$<smiles>COC1(OC)C=CC(=O)C=C1NC(=O)c1ccccc1OC(C)=O</smiles>

Chart 2. Synthesis of Quinol Derivative 4

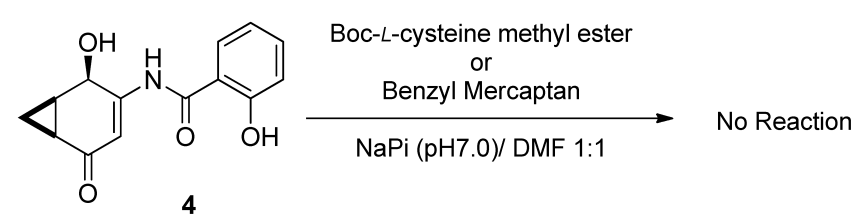

Chart 3. Reaction of $\mathbf{4}$ with Nucleophiles

upon treatment with $\mathrm{Pd}\left(\mathrm{PPh}_{3}\right)_{4}$ and dimedone. Unfortunately, although deprotection of 9 proceeded smoothly to give amine 10, a partial $\mathrm{O} \rightarrow \mathrm{N}$ acetyl migration occurred to also generate alcohol 11. We thus decided to synthesize 4 from the dienone 12, which can be prepared in two steps from 2,5-dimethoxyaniline. ${ }^{8)}$ Cyclopropanation of 12 with trimethylsulfoxonium iodide proceeded regioselectively to give $\mathbf{1 3}$ in good yield. Finally, $\mathbf{1 3}$ was successfully converted into the target 4 by removal of dimethyl acetal and subsequent stereoselective reduction. The stereochemistry of the alcohol was verified by nuclear Overhauser effect (NOE) measurement.

It is reported that DHMEQ reacts rapidly with nucleophiles like benzylthiol and cysteine derivatives to give DHMEQcysteine adducts in dimethyl sulfoxide (DMSO)/phosphine buffer. ${ }^{3)}$ Although compound $\mathbf{4}$ was submitted to the same reaction, no adduct formation was observed, even after a long reaction time (Chart 3).

Next, its inhibitory activity on NF- $\kappa \mathrm{B}$ was examined in an RAW264.7 macrophage cell line. It is known that cyclooxygenase-2 (COX-2) is expressed in the cell when NF- $\kappa \mathrm{B}$ is activated. ${ }^{9)}$ Compounds $\mathbf{1}$ and $\mathbf{4}$ were dissolved in DMSO at $1 \mathrm{mg} / \mathrm{mL}$, respectively, and $10 \mu \mathrm{L}$ was added to the cell culture. After $1 \mathrm{~h}$, the medium was washed off. The cells were treated with lipopolysaccharide (LPS) and cultured for $8 \mathrm{~h}$. Subsequently, the cells were lysed and the inhibitory activity on NF- $\kappa$ B was assesed by estimating the expression of COX-2. The production level of COX-2 was inhibited in cells treated with DHMEQ (1), but cells treated with compound $\mathbf{4}$ produced COX-2 at almost the same level as the control group (Chart 4). Therefore, we concluded that compound $\mathbf{4}$ has little or no

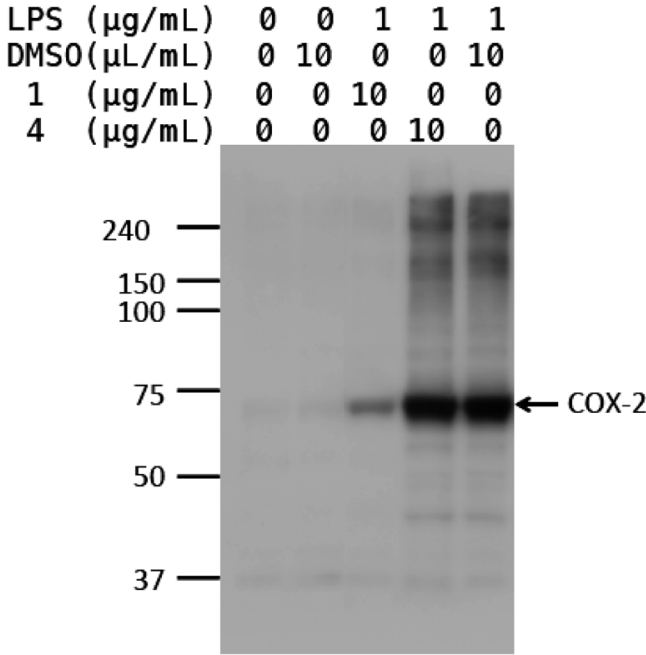

Cells were treated with or without chemicals at indicated concentrations for $1 \mathrm{~h}$ and stimulated with or without LPS at indicated concentrations for $8 \mathrm{~h}$. COX-2 expression was evaluated by Western blotting using anti-COX-2 antibody (BD, cat. No. C22420) according to the manufacturer's instructions.

Chart 4. COX-2 Expression in an RAW264.7 Macrophage Cell Line

inhibitory activity on NF- $\kappa$ B in RAW264.7 cells.

\section{Conclusion}

We have achieved the synthesis of 4, a cyclopropane derivative of DHMEQ (1), from commercially available 2,5-dimethoxyaniline in 5 steps (total yield 29\%). We showed that $\mathbf{4}$ has no recognizable inhibitory activity on NF- $\kappa \mathrm{B}$ in an RAW264.7 macrophage cell line. These results strongly support the suggestion by Umezawa and colleagues, that is, the covalent binding of the thiol group in $\mathrm{Cys}^{38}$ of p65 with the epoxide of DHMEQ is closely correlated with its inhibitory activity.

\section{Experimental}

${ }^{1} \mathrm{H}$ - and ${ }^{13} \mathrm{C}-\mathrm{NMR}$ spectra were recorded on a JEOL JNM- 
ECX-400 spectrometer at 400 and $100 \mathrm{MHz}$, respectively. Chemical shifts were expressed in $\delta$ parts per million with tetramethylsilane as internal standard $(\delta=0 \mathrm{ppm})$ for ${ }^{1} \mathrm{H}-\mathrm{NMR}$. Chemical shifts of carbon signals were referenced to $\mathrm{CDCl}_{3}$ $\left(\delta_{\mathrm{C}}=77.0 \mathrm{ppm}\right)$. The following abbreviations are used: $\mathrm{s}=$ singlet, $\mathrm{d}=$ doublet, $\mathrm{t}=$ triplet, $\mathrm{q}=$ quartet, $\mathrm{m}=$ multiplet, and br=broad. IR spectra were recorded on a Shimadzu IR Prestige-21. Mass spectra were recorded on a JEOL JMSGCmate II. Melting points were determined on a Yanaco MP-S3 micro melting point apparatus and were uncorrected.

Trimethylsulfoxonium iodide $(12.9 \mathrm{~g}, 57.4 \mathrm{mmol})$ was dissolved in DMSO $(31.5 \mathrm{~mL})$ and stirred at room temperature under an argon atmosphere. To this solution was added sodium hydride (50-72\% in mineral oil, $2.25 \mathrm{~g}$ ). After stirring for $30 \mathrm{~min}$, dienone $5(0.73 \mathrm{~g}, 2.87 \mathrm{mmol})$ in DMSO $(31.5 \mathrm{~mL})$ was added and stirred for $17 \mathrm{~h}$. To this reaction mixture was added aqueous saturated $\mathrm{NH}_{4} \mathrm{Cl}$ and extracted with ethyl acetate for 3 times. The organic phase was dried over $\mathrm{Na}_{2} \mathrm{SO}_{4}$ and concentrated in vacuo. The resulting residue was purified by silica gel column chromatography (hexane-ethyl acetate= $1: 1)$ to give $6(0.59 \mathrm{~g}, 77 \%)$.

(2,2-Dimethoxy-5-oxobicyclo[4.1.0]hept-3-en-3-yl)carbamic Acid Allyl Ester 6: ${ }^{1} \mathrm{H}-\mathrm{NMR}\left(\mathrm{CDCl}_{3}, 400 \mathrm{MHz}\right) \delta$ : 7.28 (brs, $1 \mathrm{H}), 6.65(\mathrm{~d}, J=1.2 \mathrm{~Hz}, 1 \mathrm{H}), 5.94(\mathrm{~m}, 1 \mathrm{H}), 5.36(\mathrm{dq}, J=17.2$, $1.6 \mathrm{~Hz}, 1 \mathrm{H}), 5.28(\mathrm{dd}, J=10.4,1.2 \mathrm{~Hz}, 1 \mathrm{H}), 4.64$ (q, $J=1.6 \mathrm{~Hz}$, $1 \mathrm{H}), 4.62(\mathrm{q}, J=1.6 \mathrm{~Hz}, 1 \mathrm{H}), 3.56(\mathrm{~s}, 3 \mathrm{H}), 3.27(\mathrm{~s}, 3 \mathrm{H}), 2.08$ $(\mathrm{m}, 1 \mathrm{H}), 2.00(\mathrm{~m}, 1 \mathrm{H}), 1.29(\mathrm{~m}, 1 \mathrm{H}), 0.96(\mathrm{q}, J=4.8 \mathrm{~Hz}, 1 \mathrm{H})$; ${ }^{13} \mathrm{C}-\mathrm{NMR}\left(\mathrm{CDCl}_{3}, 100 \mathrm{MHz}\right) \delta: 196.05,152.01,144.32,131.54$, $118.81,107.01,96.63,66.26,50.96,49.42,23.16,18.15,13.01$; IR (film) 1744, 1659, 1628, 1512, $1211 \mathrm{~cm}^{-1}$; high resolution (HR)-MS (electron ionization (EI)) Calcd for $\mathrm{C}_{13} \mathrm{H}_{17} \mathrm{NO}_{5}\left(\mathrm{M}^{+}\right)$ 267.1107, Found 267.1122.

Dimethyl acetal $6(0.28 \mathrm{~g}, 1.06 \mathrm{mmol})$ was dissolved in acetone $(10 \mathrm{~mL})$ and stirred at room temperature. To this solution was added $\mathrm{H}_{2} \mathrm{O}(1 \mathrm{~mL})$ and (PPTS, $\left.0.27 \mathrm{~g}, 1.06 \mathrm{mmol}\right)$. After stirring for $24 \mathrm{~h}$, aqueous saturated $\mathrm{NaHCO}_{3}$ was added and extracted with ethyl acetate for 3 times. The organic phase was dried over $\mathrm{Na}_{2} \mathrm{SO}_{4}$ and concentrated in vacuo. The resulting residue was purified by silica gel column chromatography (hexane-ethyl acetate $=1: 1)$ to give diketone $7(0.23 \mathrm{~g}, 97 \%)$.

(2,5-Dioxobicyclo[4.1.0]hept-3-en-3-yl)carbamic Acid Allyl Ester 7: ${ }^{1} \mathrm{H}-\mathrm{NMR}\left(\mathrm{CDCl}_{3}, 400 \mathrm{MHz}\right) \delta$ : 7.57 (brs, $\left.1 \mathrm{H}\right), 7.02(\mathrm{~d}$, $J=2.0 \mathrm{~Hz}, 1 \mathrm{H}), 5.92(\mathrm{~m}, 1 \mathrm{H}), 5.93$ (ddt, $J=17.6,10.8,6.0 \mathrm{~Hz}$, $1 \mathrm{H}), 5.37(\mathrm{dq}, J=17.6,1.2 \mathrm{~Hz}, 1 \mathrm{H}), 5.29(\mathrm{dq}, J=10.0,1.2 \mathrm{~Hz}$, $1 \mathrm{H}), 4.66(\mathrm{dt}, J=6.0,1.2 \mathrm{~Hz}, 1 \mathrm{H}), 2.62-2.52(\mathrm{~m}, 2 \mathrm{H}), 1.75(\mathrm{dt}$, $J=8.8,5.2 \mathrm{~Hz}, 1 \mathrm{H}), 1.66(\mathrm{q}, J=5.2 \mathrm{~Hz}, 1 \mathrm{H}) ;{ }^{13} \mathrm{C}-\mathrm{NMR}\left(\mathrm{CDCl}_{3}\right.$, $100 \mathrm{MHz}) \delta$ : 194.18, 190.52, 151.92, 138.67, 131.33, 119.14, 113.69, 66.71, 26.98, 25.40, 21.16; IR (film) 1744, 1658, 1512, $1203 \mathrm{~cm}^{-1}$; HR-MS (EI) Calcd for $\mathrm{C}_{11} \mathrm{H}_{11} \mathrm{NO}_{4}\left(\mathrm{M}^{+}\right) 221.0688$, Found 221.0688.

Diketone $7(0.10 \mathrm{~g}, 0.46 \mathrm{mmol})$ was dissolved in tetrahydrofuran (THF) $(5 \mathrm{~mL})$ and stirred at $-38^{\circ} \mathrm{C}$ under an argon atmosphere. To this solution was added L-selectride ${ }^{\circledR}(1.0 \mathrm{M}$ in THF solution, $0.47 \mathrm{~mL}$ ). After stirring for $3 \mathrm{~min}$, aqueous $10 \%$ $\mathrm{HCl}$ was added and extracted with ethyl acetate for 3 times. The organic phase was dried over $\mathrm{Na}_{2} \mathrm{SO}_{4}$ and concentrated in vacuo. The resulting residue was purified by silica gel column chromatography (hexane-acetone $=2.5: 1$ ) to give alcohol 8 (92.0 $\mathrm{mg}, 90 \%)$. The resulting solid was recrystallized from hexane-ethyl acetate to give colourless crystal.

(2-Hydroxy-5-oxobicyclo[4.1.0]hept-3-en-3-yl)carbamic Acid
Allyl Ester 8: mp $94-95^{\circ} \mathrm{C}$; ${ }^{1} \mathrm{H}-\mathrm{NMR}\left(\mathrm{CDCl}_{3}, 400 \mathrm{MHz}\right) \delta$ : $7.56(\mathrm{~s}, 1 \mathrm{H}), 6.44(\mathrm{t}, J=1.2 \mathrm{~Hz}, 1 \mathrm{H}), 5.92$ (ddt, $J=17.2,10.8$, $4.8 \mathrm{~Hz}, 1 \mathrm{H}), 5.35(\mathrm{dq}, J=17.6,1.2 \mathrm{~Hz}, 1 \mathrm{H}), 5.27$ (dq, $J=10.4$, $1.2 \mathrm{~Hz}, 1 \mathrm{H}), 4.81$ (dt, $J=7.6,1.2 \mathrm{~Hz}, 1 \mathrm{H}), 4.63$ (dt, $J=5.6$, $1.2 \mathrm{~Hz}, 2 \mathrm{H}), 3.94$ (d, $J=7.6 \mathrm{~Hz}, 1 \mathrm{H}), 1.95-2.09$ (m, 2H), 1.25 $(\mathrm{m}, 1 \mathrm{H}), 1.06$ (q, $J=5.2 \mathrm{~Hz}, 1 \mathrm{H}) ;{ }^{13} \mathrm{C}-\mathrm{NMR}\left(\mathrm{CDCl}_{3}, 100 \mathrm{MHz}\right)$ $\delta: 198.02,152.26,149.22,131.60,118.94,104.24,66.46$, 64.41, 23.62, 17.56, 12.55; IR (KBr) 3225, 1744, 1620, 1551, $1227 \mathrm{~cm}^{-1}$; HR-MS (EI) Calcd for $\mathrm{C}_{11} \mathrm{H}_{13} \mathrm{NO}_{4}\left(\mathrm{M}^{+}\right) 223.0845$, Found 223.0844.

Trimethylsulfoxonium iodide $(0.40 \mathrm{~g}, 1.80 \mathrm{mmol})$ was dissolved in DMSO $(1.6 \mathrm{~mL})$ and stirred at $0^{\circ} \mathrm{C}$ under an argon atmosphere. To this solution was added sodium hydride (50-72\% in mineral oil, $86.0 \mathrm{mg}$ ). After stirring for $20 \mathrm{~min}$ at room temperature, dienone $\mathbf{1 2}(0.12 \mathrm{~g}, 0.36 \mathrm{mmol})$ in DMSO $(2 \mathrm{~mL})$ was added and stirred for $1.5 \mathrm{~h}$. To this reaction mixture was added aqueous saturated $\mathrm{NH}_{4} \mathrm{Cl}$ and extracted with ethyl acetate for 3 times. The organic phase was dried over $\mathrm{Na}_{2} \mathrm{SO}_{4}$ and concentrated in vacuo. The resulting residue was purified by silica gel column chromatography (hexane-ethyl acetate $=1: 1)$ to give $\mathbf{1 3}(0.10 \mathrm{~g}, 92 \%)$.

$N$-(2,2-Dimethoxy-5-oxobicyclo[4.1.0]hept-3-en-3-yl)-2hydroxy-benzamide 13: Amorphous ${ }^{1} \mathrm{H}-\mathrm{NMR} \quad\left(\mathrm{CDCl}_{3}\right.$, $400 \mathrm{MHz}) \delta$ : 11.47(brs, 1H), $8.79(\mathrm{~s}, 1 \mathrm{H}), 7.45$ (m, 2H), 7.11 (d, $J=1.2,1 \mathrm{H}), 7.02(\mathrm{dd}, J=8.0,0.8 \mathrm{~Hz}, 1 \mathrm{H}), 6.94(\mathrm{dt}, J=8.0$, $0.8 \mathrm{~Hz}, 1 \mathrm{H}), 3.66(\mathrm{~s}, 3 \mathrm{H}), 3.31(\mathrm{~s}, 3 \mathrm{H}), 2.16(\mathrm{~m}, 1 \mathrm{H}), 2.06$ $(\mathrm{dt}, J=7.6,6.4 \mathrm{~Hz}, 1 \mathrm{H}), 1.35(\mathrm{dt}, J=8.4,5.2 \mathrm{~Hz}, 1 \mathrm{H}), 1.05$ (q, $J=5.2 \mathrm{~Hz}, 1 \mathrm{H}) ;{ }^{13} \mathrm{C}-\mathrm{NMR}\left(\mathrm{CDCl}_{3}, 100 \mathrm{MHz}\right) \delta: 196.59,168.93$, $161.58,142.99,135.31,125.78,119.28,118.96,114.65,110.25$, 97.10, 51.18, 49.97, 23.49, 18.32, 13.23; IR (film) 3248, 1659, 1636, 1605, 1520, 1211, $1065 \mathrm{~cm}^{-1}$; HR-MS (EI) Calcd for $\mathrm{C}_{15} \mathrm{H}_{13} \mathrm{NO}_{4}\left(\left[\mathrm{M}-\mathrm{CH}_{3} \mathrm{OH}\right]^{+}\right)$271.0845, Found 271.0845.

Dimethyl acetal $13(0.80 \mathrm{~g}, 2.62 \mathrm{mmol})$ was dissolved in acetone $(27 \mathrm{~mL})$ and stirred at room temperature. To this solution was added $\mathrm{H}_{2} \mathrm{O}(2.6 \mathrm{~mL})$ and PPTS $(0.66 \mathrm{~g}, 2.62 \mathrm{mmol})$. After stirring for $22 \mathrm{~h}$, aqueous saturated $\mathrm{NaHCO}_{3}$ was added and extracted with ethyl acetate for 3 times. The organic phase was dried over $\mathrm{Na}_{2} \mathrm{SO}_{4}$ and concentrated in vacuo. The resulting residue was purified by silica gel column chromatography (hexane-ethyl acetate $=3: 2)$ to give diketone $(0.62 \mathrm{~g}$, $92 \%)$. Diketone $(0.62 \mathrm{~g}, 2.42 \mathrm{mmol})$ was dissolved in THF $(25 \mathrm{~mL})$ and stirred at $-20^{\circ} \mathrm{C}$ under an argon atmosphere. To this solution was added L-selectride ${ }^{\circledR}(1.0 \mathrm{M}$ in THF solution, $4.9 \mathrm{~mL}$ ). After stirring for $1.5 \mathrm{~h}$, aqueous $10 \% \mathrm{HCl}$ was added and extracted with ethyl acetate for 3 times. The organic phase was dried over $\mathrm{Na}_{2} \mathrm{SO}_{4}$ and concentrated in vacuo to give alcohol $4(0.41 \mathrm{~g}, 65 \%)$. The resulting solid was recrystallized from $\mathrm{EtOH}$ to give colourless crystal.

2-Hydroxy- $N$-(2-hydroxy-5-oxobicyclo[4.1.0]hept-3-en-3-yl)benzamide 4: $\mathrm{mp} 212^{\circ} \mathrm{C}$ (dec.); ${ }^{1} \mathrm{H}-\mathrm{NMR}$ (DMSO- $d_{6}, 400 \mathrm{MHz}$ ) $\delta$ : $11.70(\mathrm{~s}, 1 \mathrm{H}), 10.95(\mathrm{~s}, 1 \mathrm{H}), 7.91(\mathrm{dd}, J=7.6,2.0 \mathrm{~Hz}, 1 \mathrm{H})$, 7.41 (dt, $J=6.4,2.0 \mathrm{~Hz}, 1 \mathrm{H}), 6.97$ (t, $J=8.0 \mathrm{~Hz}, 1 \mathrm{H}), 6.94$ (dd, $J=8.0,0.8 \mathrm{~Hz}, 1 \mathrm{H}), 6.74(\mathrm{t}, J=1.6 \mathrm{~Hz}, 1 \mathrm{H}), 6.05(\mathrm{~d}, J=8.0 \mathrm{~Hz}$, $1 \mathrm{H}), 4.79(\mathrm{dt}, J=7.2,1.6 \mathrm{~Hz}, 1 \mathrm{H}), 1.93(\mathrm{~m}, 1 \mathrm{H}), 1.79(\mathrm{~m}, 1 \mathrm{H})$, $1.16(\mathrm{dt}, J=8.0,4.0 \mathrm{~Hz}, 1 \mathrm{H}), 0.93$ (q, $J=4.8 \mathrm{~Hz}, 1 \mathrm{H}) ;{ }^{13} \mathrm{C}-\mathrm{NMR}$ $\left(\mathrm{DMSO}-d_{6}, 100 \mathrm{MHz}\right) \delta$ : 197.04, 164.69, 156.03, 149.95, $134.08,131.10,119.85,118.47,116.90,105.80,63.47,23.24$, 17.42, 12.07; IR (KBr) 3364, 1659, 1605, $1528 \mathrm{~cm}^{-1}$; HR-MS (EI) Calcd for $\mathrm{C}_{14} \mathrm{H}_{13} \mathrm{NO}_{4}\left(\mathrm{M}^{+}\right)$259.0845, Found 259.0845. 


\section{References and Notes}

1) Olivier S., Robe P., Bours V., Biochem. Pharmacol., 72, 1054-1068 (2006).

2) Matsumoto N., Ariga A., To-e S., Nakamura H., Agata N., Hirano S., Inoue J., Umezawa K., Bioorg. Med. Chem. Lett., 10, 865-869 (2000).

3) Yamamoto M., Horie R., Takeiri M., Kozawa I., Umezawa K., $J$. Med. Chem., 51, 5780-5788 (2008).

4) Compound 3a, a derivative of DHMEQ with the same stereochemistry, scarcely inhibited NF- $\kappa \mathrm{B}$ activation, but it weakly binds to p65. On the other hand, compound $\mathbf{3 b}$, a derivative of DHMEQ with the opposite stereochemistry, inhibited NF- $\kappa$ B activation dosedependently, but it does not bind to p65 (refer to ref. 5). Compound 8 was synthesized to examine structure-activity correlation of cyclopropane derivatives. The synthesis of epimer of compound $\mathbf{8}$ (cyclopropane ring and hydroxyl group are substituted as anti) and their inhibitory activities against NF- $\kappa \mathrm{B}$ would be reported in the next paper.

5) Saitoh T., Shimada C., Takeiri M., Shiino M., Ohba S., Obata R., Ishikawa Y., Umezawa K., Nishiyama S., Bioorg. Med. Chem. Lett., 20, 5638-5642 (2010).

6) Evans D. A., Tanis S. P., Hart D. J., J. Am. Chem. Soc., 103, $5813-$ 5821 (1981).

7) Corey E. J., Chaykovsky M., J. Am. Chem. Soc., 87, 1353-1364 (1965).

8) Suzuki Y., Sugiyama C., Ohno O., Umezawa K., Tetrahedron, 60, 7061-7066 (2004).

9) Vandoros G. P., Konstantinopoulos P. A., Sotiropoulou-Bonikou G., Kominea A., Papachristou G. I., Karamouzis M. V., Gkermpesi M., Varakis I., Papavassiliou A. G., J. Cancer Res. Clin. Oncol., 132, 76-84 (2006). 